\title{
PENGARUH KONSELING GIZI DENGAN MEDIA BUKU SAKU TERHADAP PERILAKU MAKAN PASIEN HNP (Hernia Nucleus Purposus) DI KLINIK SYARAF dr. KOLMAN SARAGIH MEDAN
}

\author{
Ratna Zahara ${ }^{l}$, Abdul Hairuddin Angkat ${ }^{l}$ \\ Poltekkes Kemenkes Medan ${ }^{12}$ \\ Email:' ratnazahara08@gmail.com
}

\begin{abstract}
Hernia Nucleus Pulposus (HNP) is a disease, where soft pads between vertebrae are compressed and broken, resulting in narrowing, being overweight will increase the burden on the spine and pressure on the disc, so maintaining weight with balanced nutrition will be very helpful sufferers in an effort to maintain and improve the state of HNP.

This research was conducted to determine the effect of nutritional counseling with pocket media on the eating behavior of HNP (Hernia Nucleus Pulposus) patients in the Neurology Clinic dr. Kolman Medan.

This type of research is a quasi-experimental (Quasy experiment) with a non-randomized one group design pre-test post-test design, without a control group. Held in July - August 2019, the sample was an outpatient who was diagnosed with HNP (Hernia Nucleus Purposus) who was treated at the Neurology Clinic dr. Kolman, who was selected by "Purposive Sampling" as many as 55 samples.

The results of the study, in this study based on statistical values using the difference test obtained p. Pre test knowledge value - post test knowledge p value. Value (sig) $0,000<0.05$, then $\mathrm{HO}$ is rejected and HA is accepted. For pre counseling attitudes - post counseling attitudes, $p$ value. Value (sig) $0.001<0.05$, then $\mathrm{HO}$ is rejected and HA is accepted, as well as for nutrient intake, using the difference test obtained p. Pre test intake value - Post test intake $p$ value. Value (sig) $0.001<0.05$, then $H 0$ is rejected and HA is accepted, so it can be concluded that there are differences in the average Knowledge, attitudes and behavior before counseling and after nutritional counseling with the pocket book media.
\end{abstract}

Keywords: HNP, Counseling, Pocket book, Eating behavior

\section{PENDAHULUAN}

Hernia Nucleus Pulposus (HNP) adalah suatu penyakit, dimana bantalan lunak diantara ruas-ruas tulang belakang (soft gel disc atau Nukleus Pulposus) mengalami tekanan dan pecah, sehingga terjadi penyempitan dan menekan saraf spinalis dan menimbulkan rasa nyeri yang hebat ${ }^{1}$.

Kelebihan berat badan akan meningkatkan beban pada tulang belakang dan tekanan pada diskus, struktur tulang belakang serta rawan terjadinya herniasi pada diskus lumbalis dan lebih berisiko untuk mengalami trauma ${ }^{2}$.

Sekitar $40 \%$ nyeri punggung bawah disebabkan oleh HNP. Timbulnya rasa nyeri diakibatkan penekanan pada susunan saraf tepi yang terjepit pada area tersebut, seringkali terkait dengan trauma mekanik akut, namun dapat juga sebagai akumulasi dari beberapa trauma dalam kurun waktu tertentu ${ }^{3}$.

Menurut data World Health Organication (WHO) 2012, nyeri pinggang bawah juga sering dikeluhkan oleh pegawai kantoran. Prevalensi HNP adalah 19,9\% di Spanyol. HNP lebih banyak terjadi pada perempuan $(67,5 \%)$ daripada laki-laki (33\%). Pasien HNP dari usia 31-50 tahun 1,5 kali lebih banyak dibandingkan dengan usia 16-30 tahun. Di Indonesia belum ada data namun diperkirakan $40 \%$ penduduk Jawa Tengah berusia kurang dari 65 tahun pernah menderita nyeri pinggang, prevalensi pada laki-laki $18,2 \%$ dan pada perempuan $13,6 \%{ }^{4,7}$.

Dalam Kamus Gizi (2009), dinyatakan bahwa konseling gizi adalah suatu proses komunikasi dua arah antara konselor dan pasien/klien untuk membantu pasien/ klien mengenali dan mengatasi masalah gizi ${ }^{5}$.

Media buku saku merupakan suatu media untuk menyampaikan pesan-pesan gizi dalam bentuk buku, baik berupa tulisan maupun gambar. Hasil penelitian Nur Pratiwi tahun 2015 menunjukkan bahwa ada pengaruh intervensi dengan menggunakan metode buku saku terhadap peningkatan skor pengetahuan tentang pemilihan jajanan sehat ${ }^{6}$. 


\section{TUJUAN PENELITIAN}

1. Menilai pengetahuan sebelum dan setelah diberikan konseling gizi dengan media buku saku pada pasien penderita HNP (hernia nucleus pulposus).

2. Menilai sikap sebelum dan setelah diberikan konseling gizi dengan media buku saku pada pasien penderita HNP (hernia nucleus pulposus).

3. Menilai perilaku makan sebelum dan setelah di berikan konseling gizi dengan media buku saku pada pasien penderita HNP (hernia nucleus pulposus).

4. Menganalisa pengaruh pemberian konseling gizi dengan media buku saku terhadap perilaku makan, pengetahuan dan sikap pada pasien HNP (Hernia Nucleus Pulposus).

\section{METODE PENELITIAN \\ Desain, Subjek, dan Waktu}

Jenis penelitian yang digunakan adalah eksperimen semu (quasy experiment) dengan rancangan non-randomized one group pre-test posttest design. Penelitian ini dilakukan tanpa kelompok kontrol. Intervensi diberikan pada kelompok sampel yang sama dinilai sebelum dan setelah intervensi ${ }^{8,9}$.

Cara penentuan sampel yang digunakan adalah "Purposive Sampling" yaitu teknik penetapan sampel dengan cara memilih sampel diantara populasi sesuai dengan yang peneliti kehendaki (Nursalam, 2008) ${ }^{10}$, yaitu Penderita HNP yang datang pada saat dilakukan penelitian, sebanyak 55 orang, dengan kriteria inklusi yang harus dimiliki responden

1. Pasien yang bersedia menjadi responden

2. Pasien yang bisa baca dan tulis

3. Pasien yang bersedia meluangkan waktunya untuk konseling

4. Pasien yang berusia $45-65$ tahun

Penelitian ini dilakukan di Klinik Syaraf dr. Kolman, Sei Belutu, Medan Selayang, pada bulan April - Agustus 2019. Pengumpulan data di lakukan selama 6 minggu, pada minggu kedua bulan Juli hingga akhir bulan Agustus 2019

\section{Jenis dan Cara Pengumpulan Data}

Data dalam penelitian ini terdiri atas 2 jenis data yaitu data primer dan data sekunder ${ }^{7,8,6}$.

Data primer meliputi data karakteristik sampel, pengetahuan, sikap, dan tindakan responden, sementara data sekunder meliputi data laboratorium.yang didapatkan dari rekam medik klinik dr. Kolman Saragih.

\section{Pengolahan dan Analisis Data}

Analisa data diperoleh dengan menggunakan perhitungan uji statistik memakai program SPSS. Analisa univariat, untuk mendeskripsikan setiap variabel penelitian. Analisis bivariat, dilakukan untuk melihat pengaruh pemberian konseling gizi dengan media buku saku terhadap perilaku makan, pengetahuan dan sikap pada pasien HNP (Hernia Nucleus Pulposus) $)^{8,18}$.

\section{HASIL DAN PEMBAHASAN}

Karakteristik Subjek

Adapun karakteristik Pasien HNP sebagai subjek meliputi jenis kelamin, pekerjaan dan umur.

Tabel 1. Karakteristik Pasien HNP di Klinik Syaraf dr. Kolman Saragih

\begin{tabular}{|c|c|c|}
\hline \multirow{2}{*}{ Karakteristik } & \multicolumn{2}{|c|}{ Jumlah } \\
\hline & n & $\%$ \\
\hline \multicolumn{3}{|l|}{ Jenis Kelamin } \\
\hline $\mathrm{L}$ & 30 & 54,6 \\
\hline$P$ & 25 & 45,4 \\
\hline Total & 55 & 100 \\
\hline \multicolumn{3}{|l|}{ Pekerjaan } \\
\hline PNS & 18 & 32,7 \\
\hline Non PNS & 21 & 21,8 \\
\hline Tidak bekerja & 25 & 45,5 \\
\hline Total & 55 & 100 \\
\hline \multicolumn{3}{|l|}{ Usia } \\
\hline 45 - 50 Tahun & 12 & 21,8 \\
\hline 51 - 54 Tahun & 6 & 10,9 \\
\hline 55 - 60 Tahun & 14 & 25,5 \\
\hline 61 - 65 Tahun & 23 & 41,8 \\
\hline Total & 55 & 100,0 \\
\hline
\end{tabular}
berjenis kelamin laki-laki sebesar 54,6\% sampel yang diteliti. HNP lebih banyak terjadi pada laki-laki dibandingkan wanita, dengan perbandingan 4:1 menyerang pada usia $>30 \quad 50$ tahun (Peter A. Casigrando, 1953). Prosentase kasus HNP yang terjadi pada lumbal 90\%, servikal 515 dan sisanya mengenai daerah thorakal (Krupp, 1971) (11,12. $^{4}$.

Sedangkan dari umur, persentase tertinggi pada kelompok umur 61 -61 tahun sebesar 41,8\% dan kelompok umur 55 - 60 tahun sebesar 25,5\%. Hal ini disebabkan karena kepadatan tulang terjadi pada usia dewasa yang mengakibatkan tingkat elastisitas tulang semakin berkurang, tulang menjadi lebih kaku ${ }^{13,14,15}$.

Berdasarkan pekerjaan, sampel tidak bekerja sebesar 45,5\%. Pekerjaan merupakan salah satu faktor yang dapat menyebabkan terjadinya HNP. Kecelakaan yang berat dapat mengakibatkan fungsi dari syaraf menjadi kaku yang menyebabkan HNP. Pada penelitian ini banyak sampel merupakan ibu 
rumah tangga yang banyak melakukan pekerjaan rumah tangga. Pekerjaan rumah tangga yang dilakukan terus menerus tanpa adanya peregangan akan mengakibatkan kekakuan pada tulang belakang $^{16,17}$.

Tabel 2. Pengetahuan Pasien HNP di Klinik Syaraf dr. Kolman Saragih

\begin{tabular}{lcccc}
\hline \multirow{2}{*}{$\begin{array}{l}\text { Peng } \\
\text { etah } \\
\text { uan }\end{array}$} & \multicolumn{2}{l}{$\begin{array}{l}\text { Pengetahuan } \\
\text { Sebelum diberi } \\
\text { konseling }\end{array}$} & \multicolumn{2}{c}{$\begin{array}{l}\text { Pengetahuan } \\
\text { Sesudah diberi } \\
\text { konseling }\end{array}$} \\
\cline { 2 - 5 } & $\mathbf{n}$ & \% & n & \% \\
\hline Baik & 7 & 12,7 & 50 & 90,9 \\
Kurang & 48 & 87,3 & 5 & 9,1 \\
\hline Total & 55 & 100 & 55 & 100 \\
\hline
\end{tabular}

Pada tabel 2 menunjukkan kategori Pengetahuan Pre dan Post Test pada pasien HNP, dimana untuk Pre test, memiliki kategori pengetahuan Kurang sebanyak $87,3 \%$ dan kategori baik sebanyak $12,7 \%$. Untuk post test, kategori baik sebesar 90,9\% dan kategori kurang $9,1 \%$.

Tabel 3. Pengaruh Pemberian Konseling Dengan Media Buku Saku Terhadap Pengetahuan

\begin{tabular}{|c|c|c|c|c|}
\hline & $\mathrm{n}$ & Mean & $\begin{array}{c}\text { Std. } \\
\text { Deviation }\end{array}$ & p.value \\
\hline Pre test & & & & \multirow{3}{*}{.000} \\
\hline $\begin{array}{l}\text { Pengetahuan } \\
\text { Post test }\end{array}$ & 55 & 4.16 & 1.450 & \\
\hline Pengetahuan & 55 & 8.18 & 1.203 & \\
\hline
\end{tabular}

Dari tabel 3 nilai rata-rata pengetahuan sebelum diberikan konseling adalah 4,16 dengan std. Deviation 1,450 . Setelah pemberian konseling gizi dengan media buku saku, nilai rata-rata pengetahuan 8,18 dengan std. Deviation 1,203. Pada penelitian ini berdasarkan nilai statistiknya dengan menggunakan uji perbedaan diperoleh $\mathrm{p}$. Value pengetahuan pre test - pengetahuan post test nilai p. Value (sig) $0,000<0,05$, maka $\mathrm{H} 0$ ditolak dan HA diterima, sehingga dapat disimpulkan bahwa ada perbedaan rata-rata antara pengetauan pre test dengan post test dengan strategi pemberian konseling menggunakan media Buku Saku.

Tabel 4. Sikap Pasien HNP di Klinik Syaraf dr. Kolman Saragih

\begin{tabular}{lcccc}
\hline Sikap & $\begin{array}{c}\text { Sikap Sebelum } \\
\text { diberikan } \\
\text { konseling }\end{array}$ & \multicolumn{2}{c}{$\begin{array}{c}\text { Sikap } \\
\text { Sesudah } \\
\text { diberikan } \\
\text { konseling }\end{array}$} \\
\cline { 2 - 5 } & $\mathbf{n}$ & $\mathbf{\%}$ & $\mathbf{n}$ & $\mathbf{\%}$ \\
\hline Baik & 14 & 25,5 & 53 & 96,4 \\
Kurang & 41 & 74,5 & 2 & 3,6 \\
\hline Total & $\mathbf{5 5}$ & $\mathbf{1 0 0}$ & $\mathbf{5 5}$ & $\mathbf{1 0 0}$ \\
\hline
\end{tabular}

Pada tabel 4 menunjukkan kategori Sikap Pre dan Post Konseling pada pasien HNP, dimana untuk Pre Konseling, memiliki kategori Sikap Kurang sebanyak $74,5 \%$ dan kategori baik sebanyak $25,5 \%$. Untuk post konseling, kategori baik sebesar 96,4\% dan kategori kurang 3,6\%.

Tabel 5. Pengaruh Pemberian Konseling Dengan Media Buku saku Terhadap Sikap

\begin{tabular}{lcccc} 
& $\mathrm{n}$ & Mean & $\begin{array}{c}\text { Std. } \\
\text { Deviation }\end{array}$ & p.value \\
\cline { 2 - 5 } Pre & & & & \\
$\begin{array}{l}\text { konseling } \\
\text { Post }\end{array}$ & 55 & 5.15 & 1.768 & .000 \\
konseling & 55 & 8.76 & 981 & \\
\hline
\end{tabular}

Dari tabel 5 nilai rata-rata sikap sebelum diberikan konseling adalah 5,15 dengan std. Deviation 1,768. Setelah pemberian konseling gizi dengan media buku saku, nilai rata-rata Sikap 8,76 dengan std. Deviation 0,981. Pada penelitian ini berdasarkan nilai statistiknya dengan menggunakan uji perbedaan diperoleh p. Value Sikap pre konseling - Sikap post konseling, nilai p. Value (sig) $0,001<0,05$, maka H0 ditolak dan HA diterima, sehingga dapat disimpulkan bahwa ada perbedaan rata-rata antara sikap pre konseling dengan sikap post konseling dengan strategi pemberian konseling menggunakan media Buku Saku.

Konseling Gizi yang dilakukan memberikan pemahaman kepada responden sehingga responden memiliki kemampuan untuk mengkonseptualisasikan masing-masing nilai pada waktu merespons, dengan jalan mengidentifikasi karakteristik nilai atau membuat pertimbangan-pertimbangan ${ }^{16,19}$.

Tabel 6. Asupan Gizi Pasien HNP di Klinik Syaraf dr. Kolman Saragih

\begin{tabular}{lcccc}
\hline \multirow{2}{*}{ Asupan } & $\begin{array}{c}\text { Sebelum } \\
\text { diberikan } \\
\text { Konseling }\end{array}$ & \multicolumn{2}{c}{$\begin{array}{c}\text { Sesudah } \\
\text { diberikan } \\
\text { Konseling }\end{array}$} \\
\cline { 2 - 5 } n & $\mathbf{\%}$ & $\mathbf{n}$ & $\mathbf{\%}$ \\
\hline $\begin{array}{c}\text { Energi } \\
\text { Baik }\end{array}$ & 24 & 43,6 & 45 & 81,8 \\
Kurang & 31 & 56,4 & 10 & 18,2 \\
\hline Total & $\mathbf{5 5}$ & $\mathbf{1 0 0}$ & $\mathbf{5 5}$ & $\mathbf{1 0 0}$ \\
\hline Protein & & & & \\
Baik & 7 & 12,7 & 52 & 87,2 \\
Kurang & 48 & 87,3 & 3 & 12,8 \\
\hline Total & $\mathbf{5 5}$ & $\mathbf{1 0 0}$ & $\mathbf{5 5}$ & $\mathbf{1 0 0}$ \\
\hline Karbohidrat & & & & \\
Baik & 11 & 20,0 & 39 & 70,9 \\
Kurang & 44 & 80,0 & 16 & 29,1 \\
\hline
\end{tabular}




\begin{tabular}{lcccc} 
Total & $\mathbf{5 5}$ & $\mathbf{1 0 0}$ & $\mathbf{5 5}$ & $\mathbf{1 0 0}$ \\
\hline Lemak & & & & \\
$\quad$ Baik & 27 & 49,1 & 38 & 69,0 \\
$\quad$ Kurang & 28 & 50,9 & 17 & 31,0 \\
\hline Total & $\mathbf{5 5}$ & $\mathbf{1 0 0}$ & $\mathbf{5 5}$ & $\mathbf{1 0 0}$ \\
\hline Kalsium & & & & \\
$\quad$ Baik & 1 & 5,5 & 37 & 66,3 \\
$\quad$ Kurang & 54 & 94,5 & 18 & 32,7 \\
\hline Total & $\mathbf{5 5}$ & $\mathbf{1 0 0}$ & $\mathbf{5 5}$ & $\mathbf{1 0 0}$ \\
\hline
\end{tabular}

Pada tabel 6 menunjukkan kategori asupan pada pasien HNP di Klinik dr. Kolman Saragih. Asupan energi sebelum konseling paling banyak asupan energi dengan kategori kurang sebesar 56,4\% dan baik sebesar 43,6\%, untuk asupan protein $87,3 \%$ untuk kategori kurang dan 12,7\% kategori baik. Asupan karbohidrat sebelum konseling berada pada kategori kurang sebesar $80 \%$ dan baik 20\%, Lemak dengan kategori kurang 50,9\% dan baik 49,1\%. Dari Asupan Kalsium, kategori kurang 94,5\% dan baik 5,5\%. Setelah dilakukan intervensi dengan pemberian konseling gizi menggunakan media buku saku, menunjukkan peningkatan asupan yang lebih baik pada pasien HNP. Asupan energi setelah mendapat konseling, 81,8\% asupan energi sudah kategori baik, meskipun masih ada kategori kurang sebesar 18,2\%, asupan protein dengan kategori baik sebesar $87,2 \%$, Karbohidrat di kategori baik sebesar 70,9\%, lemak kategori baik 69\% dan Kalsium 60\% masuk kategori baik.

Tabel 7. Pengaruh Pemberian Konseling Dengan Media Buku saku Terhadap Asupan energi

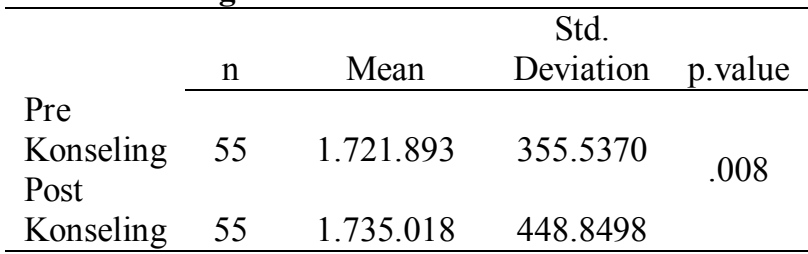

Dari tabel 7 nilai rata-rata Asupan energi sebelum diberikan konseling adalah 1.721.893 dengan std. Deviation 355.5370. Setelah pemberian konseling gizi dengan media buku saku, nilai rata-rata asupan gizi 1.735.018 dengan std. Deviation 448.8498. Pada penelitian ini berdasarkan nilai statistiknya dengan menggunakan uji perbedaan diperoleh p. Value pengetahuan pre test - pengetahuan post test nilai $\mathrm{p}$. Value (sig) $0,008<0,05$, maka H0 ditolak dan HA diterima, sehingga dapat disimpulkan bahwa ada perbedaan rata-rata antara Asupan energi pre test dengan post test dengan strategi pemberian konseling menggunakan media Buku Saku.

Asupan Protein

Pengaruh pemberian konseling gizi dengan media buku saku terhadap Asupan Protein sebelum (pre test) dan sesudah (post test) dapat dilihat pada tabel 8 berikut:

Tabel 8. Pengaruh Pemberian Konseling Dengan Media Buku saku Terhadap Asupan Protein

\begin{tabular}{|c|c|c|c|c|}
\hline & $\mathrm{n}$ & Mean & $\begin{array}{l}\text { Std. } \\
\text { Deviation }\end{array}$ & p.value \\
\hline $\begin{array}{l}\text { Pre } \\
\text { test }\end{array}$ & 55 & 68.875 & 17.5506 & .001 \\
\hline $\begin{array}{l}\text { Post } \\
\text { test }\end{array}$ & 55 & 69.069 & 18.7196 & \\
\hline
\end{tabular}

Dari tabel 8 nilai rata-rata Asupan Protein sebelum diberikan konseling adalah 68.875 dengan std. Deviation 17.5506. Setelah pemberian konseling gizi dengan media buku saku, nilai rata-rata asupan gizi 69.069 dengan std. Deviation 18.7196. Pada penelitian ini berdasarkan nilai statistiknya dengan menggunakan uji perbedaan diperoleh p. Value pengetahuan pre test - pengetahuan post test nilai $\mathrm{p}$. Value (sig) 0,001 <0,05, maka H0 ditolak dan HA diterima, sehingga dapat disimpulkan bahwa ada perbedaan rata-rata antara Asupan energi pre test dengan post test dengan strategi pemberian konseling menggunakan media Buku Saku.

Tabel 9. Pengaruh Pemberian Konseling Dengan Media Buku saku Terhadap Asupan Protein

\begin{tabular}{lcccc}
\hline & & & $\begin{array}{c}\text { Std. } \\
\text { Deviation }\end{array}$ & p.value \\
\cline { 2 - 5 } $\begin{array}{l}\text { Pre } \\
\text { test }\end{array}$ & 55 & 435.558 & 251.4553 & .001 \\
$\begin{array}{l}\text { Post } \\
\text { test }\end{array}$ & 55 & 474.616 & 257.8018 & \\
\hline
\end{tabular}

Dari tabel 9 nilai rata-rata Asupan Protein sebelum diberikan konseling adalah 435.558 dengan std. Deviation 251.4553. Setelah pemberian konseling gizi dengan media buku saku, nilai rata-rata asupan gizi 474.616 dengan std. Deviation 257.8018 . Pada penelitian ini berdasarkan nilai statistiknya dengan menggunakan uji perbedaan diperoleh p. Value Asupan pre test - Asupan post test nilai p. Value (sig) $0,001<0,05$, maka H0 ditolak dan HA diterima, sehingga dapat disimpulkan bahwa ada perbedaan rata-rata antara Asupan energi pre test dengan post test 
dengan strategi pemberian konseling menggunakan media Buku Saku.

Perilaku dapat dilihat dari perilaku yang ditampilkan. Pada penelitian ini, pemberian konseling Gizi dengan media buku saku memberikan perubahan pola pikir pada responden yang berdampak pada perubahan perilaku makannya, dimana konseling individual ini adalah suatu bentuk pendekatan yang digunakan dalam asuhan gizi untuk menolong individu dan keluarga memperoleh pengertian yang lebih baik tentang dirinya dan permasalahan yang dihadapi sehingga mereka akan merubah perilakunya $^{19,20,21,21}$.

\section{Kesimpulan}

1. Ada perbedaan Pengetahuan sebelum dan sesudah diberikan konseling dengan menggunakan media buku saku kepada pasien HNP (Hernia Nucleus Pulposus) di Klinik dr. Kolman Saragih, dengan nilai rata-rata sebelum 4,16 dan setelah konseling menjadi 8,18

2. Ada perbedaan Sikap sebelum dan sesudah diberikan konseling dengan menggunakan media buku saku kepada pasien HNP (Hernia Nucleus Pulposus) di Klinik dr. Kolman Saragih, dengan nilai rata-rata sebelum 5,15 dan setelah konseling menjadi 8,76.

3. Ada perbedaan perilaku makan terkait asupan energi, protein dan kalsium sebelum dan sesudah diberikan konseling dengan menggunakan media buku saku kepada pasien HNP (Hernia Nucleus Pulposus) di Klinik dr. Kolman Saragih, dengan nilai rata-rata untuk asupan energi sebelum 1721.893 dan setelah konseling menjadi 1735.018, untuk asupan Protein sebelum konseling rata-rata mendapat nilai 68.875 dan setelah konseling 69.069 serta nilai untuk asupan Kalsium sebelum konseling435.558 dan setelah konseling 474.616.

4. Ada Pengaruh pemberian konseling dengan media Buku Saku terhadap perilaku Pasien HNP (Hernia Nucleus Pulposus).

\section{DAFTAR PUSTAKA}

1. Pinzon, Rizaldy. 2012. Profil klinis pasien nyeri punggung bawah akibat Hernia Nukleus Pulposus ; Jurnal penelitian, Jogjakarta, hal 749.

2. Fernandez et al, 2009. Data Prevalensi Henia Nukleus Pulposus - HNP di Spayol.

3. Lubis, Namora Lumangga, 2011. Memahami Dasar-dasar Konseling dalam Teori dan Praktek. Jakarta : Kencana.

4. Meliawan S., 2009. Diagnosis dan Tatalaksana HNP Lumbal Dalam : Diagnosa da tatalaksana ke gawat darurat Tulang Belakang. Jakarta. Sagung Seto, P; 62-87.

5. Budiman \& Riyanto A. 2013. Kapita selekta Kuesioner Pengetahuan dan Sikap Dalam
Penelitian Kesehatan. Jakarta : Salemba Medika pp 66-69.

6. Supariasa IDN . Pendidikan dan konsutasi Gizi. Jakarta: EGC ; 2012.

7. Depkes RI. 2009. Profil Kesehatan Indonesia. Jakarta : Depkes RI.

8. B. Shetrzer \& S. C. Stone.(1980). Fundamentals Of conseling. Boston : Houghton Mifflin.

9. Khumaidi. 1994. Gizi Masyarakat. PT. BPK Gunung Mulia. Jakarta.

10. Helmi, 2012. Buku Ajar Keperawatan Medikal Bedah. Jakarta : Jogyakarta.

11. Lotke dkk, 2008. Buku Ajar Keperawatan medikal Bedah. Jakarta : Jogyakarta.

12. Meliana L. dkk., 2012. Konsensus Nasional Diagnosa dan Penatalaksanaan Nyeri Surabaya ; Pusat Penerbitan dan pencetaan UNAIR (AUP) PP. 1-9.

13. Mansur. (2014). Implementasi Pendidikan Karakter di Satuan pendidikan . Artikel LPML: Sulawesi Selatan.

14. Muttaqin, Arif. 2008. Buku Ajar Asuhan Keperawatan Klien dengan ganguan sistem persyarafan. Jakarta : Salemba Medika

15. Notoatmodjo, S. 2007. Pendidikan dan Perilaku Kesehatan. Cetakan 2. Jakarta : PT. Rineka Cipta.

16. Notoatmodjo, Soekidjo. 2012. Promosi Kesehatan dan Perilaku Kesehatan. Jakarta : Rineka Cipta.

17. Nurarif. A. H. dan Kusuma. H. 2015. Aplikasi Asuhan Keperawatan Berdasarkan Diagnosa medis \& Nanda NIC-NOC. Jogjakarta : MediAction.

18. Nursalam, 2008. Konsep dan penerapan Metodologi Penelitian Keperawatan. Jakarta : Salemba Medika.

19. Bimo, Walgito. 2003. Pengantar Psikologi Umum. Yogyakarta : ANDI.

20. Persagi. 2010. Penuntun Konseling Gizi. Jakarta: PT. Abadi.

21. Persatuan Ahli Gizi Indonesia. 2013. Konseling Gizi, Penerbit Penebar Swadaya Grup. Jakarta $2013: 12-61$

22. Purwaningrum N. F. 2008. Hubungan Antara citra Raga dan perilaku Makan pada remaja Putri. Skripsi. Falkutas Psikologi Universitas Muhammadiyah Surakarta.

23. PERDOSSI (Perhimpunan Dokter Saraf Indonesia). 2002. Prevalensi Nyeri.

24. Palupi, RD. 2014. Analisis Faktor-Faktor yang Mempengaruhi Status Gizi Baik Dan Gizi Kurang Pada Balita di Desa Dukuhwaluh Kecamatan Kembaran Kabupaten Banyumas. Skripsi. Jurusan Keperawatan Fakultas Kedokteran dan Ilmu-ilmu Kesehatan Unsoed Kementrian Pendidikan dan Kebudayaan Purwokerto di akses pada tanggal 17 Mei 2015. 